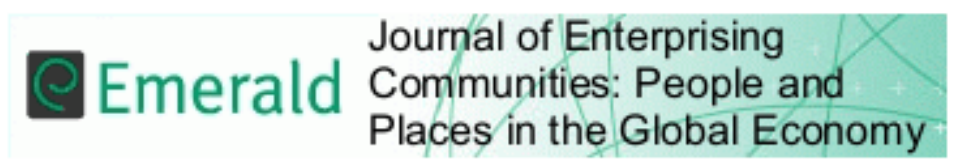

\title{
Sustainable prosperity and enterprises for Māori communities in Aotearoa New Zealand: A review of the literature
}

\begin{tabular}{|r|l|}
\hline Journal: & $\begin{array}{l}\text { Journal of Enterprising Communities: People and Places in the Global } \\
\text { Economy }\end{array}$ \\
\hline Manuscript ID & JEC-07-2020-0133.R1 \\
\hline Manuscript Type: & Academic Papers \\
\hline Keywords: & $\begin{array}{l}\text { Indigenous people, rangatahi (young New Zealand Māori adults), } \\
\text { sustainable enterprises, well-being, workplace, whānau (New Zealand } \\
\text { Māori family/community) }\end{array}$ \\
\hline
\end{tabular}

\section{SCHOLARONE ${ }^{\text {M }}$ Manuscripts}


Sustainable prosperity and enterprises for Māori communities in Aotearoa New

\section{Zealand: A review of the literature}

\section{Introduction}

The purpose of this paper is to explore recent literature on ways that Māori (the Indigenous people of Aotearoa New Zealand) have developed strategies to attain sustainable prosperity and develop effective enterprises. The introduction discusses the contextual and historical background realities for Māori, and the rights of Indigenous people. Next, section one looks at workplace pathways for rangatahi (young adult Māori) and whanau (family). Following that, section two outlines the aim of the literature review and the research methodology/protocols. Section three contains the review of the literature which includes four key themes for mana (sociocultural wellbeing) constructs, wairua (spirituality) and cultural taxation. Finally, section four (the conclusions) draws together the findings from the literature.

\section{$\underline{\underline{\text { Introduction }}}$}

Sustainable prosperity, regular incomes, nourishment and adequate housing are basic human rights that are key to supporting health and wellbeing. Yet, within New Zealand, this is far from the lived reality. Lamentably, this is particularly prevalent for Māori, the Indigenous peoples of New Zealand who in 2013 comprised $15 \%$ of the population (Statistics New Zealand Tatauranga Aotearoa, 2013) and this percentage is predicted to rise (Statistics New Zealand Tatauranga Aotearoa, 2018). Furthermore, Māori are a young population with median ages for Māori males and females 23 years and 26 years, respectively. Aotearoa New Zealand comprises three islands situated in the South Pacific, to the southeast of Australia. New Zealand proclaims to be a bi-cultural nation within which two parties co-exist. These parties are Māori and all people who came to live in New Zealand post Māori settlement, who are usually referred to as Tauiwi. 
The loss of land for Māori has destroyed their historic economic base, along with a wearing down of their culture, which has resulted in long-term, intergenerational implications for prosperity. Many Māori, prior to colonisation and during the $19^{\text {th }}$ century were successful entrepreneurs and led commerce nationally (Henry, Dana, \& Murphy, 2018; Hipango \& Dana, 2012). However, colonisation in the mid-1800s put a strain on whānau capability and economy, particularly due to changed circumstances in regards to land ownership, maintenance of culture, wellbeing and nutrition (Martin, 2017; Panelli \& Tipa, 2007). This loss of land ownership and access to places to hunt and gather food, had a negative influence on access to social capital, such as the established relationships which are based on reciprocity and trust (Light \& Dana, 2013). Furthermore, during this period some of the pivotal culturally rich values, beliefs and practices, such as the intrinsic value of mana wairua (spirituality) and the cornerstone of te reo Māori (Māori language) were negatively affected (Walker, 1990). Henry et al., (2018) call for a rekindling of the Māori entrepreneurial spirit with a keen desire for demanding emancipation for Māori iwi and hāpu (communities).

Colonisation has continued to negatively impact the Māori economy over ensuing generations, thus limiting the opportunities for Māori wellbeing to flourish socially, culturally, economically and environmentally. In order to counter this, it is critical that we build an understanding of successful workplace and Indigenous community enterprises pathways within which the cultural uniqueness, entrepreneurship and leadership talent - from a kaupapa Māori (Māori approach and principles) perspective, are unleashed. Such a counter approach is aligned to the clarion call for a research methodology that proposes being 'for, with and about Māori'. Our aim is to utilise this understanding to support change that will provide sustainable prosperity for rangatahi (young Maori adults) and whānau (New Zealand Māori family/community).

\section{Indigenous Peoples}


The grim, long-term, intergenerational outcomes of colonisation are not unique to Aotearoa New Zealand. Colonisation in many countries, such as the Philippines, Canada, United States and Australia has resulted in severely marginalised Indigenous peoples who have become hidden populations frequently impacted by high unemployment rates ( $\mathrm{Au}$, 2000; Bishop, 2005; Chamberlain \& Caygill, 2013; Authors and colleagues, 2017). This reality counters the United Nation's declaration to support the rights of Indigenous Peoples. The international stance on the provisions of the United Nation's (2008) Declaration on the Rights of Indigenous Peoples states:

\begin{abstract}
Indigenous peoples have the right, without discrimination, to the improvement of their economic and social conditions, including, inter alia in the areas of education, employment, vocational training and retraining, housing, sanitation, health and social security (Article 21.1).
\end{abstract}

Relatedly, this review is wedged within the legal, ethical and moral weight of the Treaty of Waitangi ${ }^{1}$. The Treaty's main emphasis was/is to provide partnership, participation and protection of Māori culture between Māori and non-Māori communities. There are both Māori and English language texts of the Treaty. Most signatories to the Treaty $(500+)$ placed their signatures on the Māori language text, correctly referred to as Te Tiriti o Waitangi (1840). The Waitangi Tribunal (2014) concluded that Ngāpuhi (a particular tribe) chieftains, and other signatories, did not cede mana (sovereignty) as a consequence of signing this Māori language document (Waitangi Tribunal, 2014; Williams, 2014). Hence, the legal, ethical and moral weight of Te Tiriti o Waitangi in international law gives protection from the provisions of the

\footnotetext{
${ }^{1}$ The Treaty of Waitangi was signed in 1840 by representatives of the British government and over 500 Māori Chiefs.
} 
United Nation's (2007) Declaration on the Rights of Indigenous Peoples (which the New Zealand Government signed).

One of the principles of international law is the 'contra proferentem' rule that places responsibility on the writer/drafter of a contract to ensure that there is no uncertainty or terms that are ambiguous as this may work against the benefits of one party in a contractual agreement. Under this rule, the Indigenous Treaty version becomes the version to acknowledge and implement (Jackson, 1989). Therefore, the Māori language version of the treaty becomes the blueprint of moving forward to address matters that benefit both parties, above and beyond.

Notwithstanding recent concerted efforts from many entities and respective governments, little regard has been afforded the Māori version of the Treaty perhaps relegating it to a lip service or ticket clipping exercise. We suggest that if the "contra proferentem' rule had been adhered to in the writing of the English and Māori versions of the treaty, benefits to both parties may have been better protected. For example, if the Treaty of Waitangi principles had been enacted towards whānau economy, arguably this may have provided another possible pathway forward in improvement for overall whānau wellbeing across many generations (Gibson et al., 2017; Simpson, Duncanson, Oben, \& Wicken, 2016).

\section{Workplace Pathways for Rangatahi and Whānau}

Young people in general, but especially those leaving school early with few or no qualifications, can be vulnerable to the labour market and its fluctuations. In a 2018 report from Statistics New Zealand Tatauranga Aotearoa (Statistics New Zealand, 2018) there was an improvement in the proportion of young Māori not earning or learning, with five in every six Māori rangatahi aged 15-24 years in some type of education, training, or work. Although, the rate of unemployment of all Māori in 2018 was at a ten year low, it was still double the 
rate for all New Zealanders. The recent increase in rangatahi in the workforce and or tertiary education is affirming. Complicating this situation are the regional differences in rates of unemployment. Northland, Auckland and the East Coast have the highest unemployment rates in New Zealand and these are regions that also have high Māori populations.

A decade ago, the young people 'Not in Education, Employment or Training' report (NEET) found that the 'Not in Education, Employment or Training' rate for Māori aged 1524 was $14.9 \%$, compared to $8.2 \%$ for non-Māori (Department of Labour, 2009). Of concern, was the even higher NEET rate for Māori males aged 20-24 years (19.1\%) which had been steadily climbing since 2007. According to the Department of Labour (2009) this indicated that many rangatahi were not going on to training, education or work beyond school, thus were experiencing long-term unemployment. In response, structural and social realignment of the State Sector, tertiary education, government policies and private training enterprises were established to provide a cultural match and fit for rangatahi for pathways to employment (Phillips \& Mitchell, 2010).

However, after criticism that the NEET data did not capture some young people shifting between low paid and/or short-term jobs and/or low level tertiary education, a later review was commissioned that applied a broader definition of limited employment. Thus, the Ministry of Education 2018 review of Youth at Risk of Limited Employment Outcomes was commissioned. It looked at 24 year olds who had been in limited employment every year since they were 16 year of age, and found that for the entire population it was $8 \%$, but much higher for Māori at 16\% (McGirr \& Earle, 2019). Furthermore, of the 15\% of the entire population who were in limited employment for the majority of years since they were aged 16 years of age and are considered to be at medium risk of lifetime limited employment, the proportion for Māori was $27 \%$. If these findings are indicative of the lived realities now for 
Māori young people, it would appear that a much higher proportion of Māori are at risk, in regards to long-term unemployment, in comparison to non-Māori. Furthermore, it seems that there has been little change for the better over the last ten years. We contend that our research that explores avenues for practices of sustainable enterprise to promote prosperity from a kaupapa Māori (Māori approach and principles) lens will provide positive steps forward in turning the tide. We suggest that future research identifies positive aspects of whānau culture that support successful pathways. For example, increased levels of mana (sociocultural and psychological wellbeing) is one unique avenue of considering pathways in the workplace for rangatahi (young adults) and whānau (New Zealand Māori family/community).

A reasoned approach to identify the cultural consciousness of an individual, an organisation or a workplace is based on the Māori construct of mana. Mana is taken to mean giving a person or entity the authority to lead, monitor, and regulate explorations and activities, and to make decisions about psycho-socio-political matters. A person or entity's mana can increase on account of successful interventions or ventures - or decrease if the converse applies. A study by a cohort of Te Arawa researchers (Author and colleagues 2014) concluded that five mana themes were prime indicators of 'success, as Māori'. These themes of mana motuhake (identity, attitudes and values), mana tū (building resilience, courage and positive relationships), mana ūkaipō (place and environmental functions), mana tangatarua (alternating with the transition from education to work) and mana whānau (family) played a part in guiding the thinking and propositioning of our developing inroads to make changes that would improve structures and systems for positive wellbeing in the workplace and wider community.

Furthermore, increased levels of positive mana whānau (family) relations and the adherence to empowering people, unconditional hospitality and stewardship between and 
within whānau membership can be linked to the commitment of institutions and organisations. Studies, however, exploring whānau values and conceptions of the workplace environment are scarce, specifically, the extent to which whānau values are formally espoused in New Zealand organisations. Therefore, the benefits that this form of cultural advocacy entails for workplace relationships, remain largely untapped and unidentifiable.

\section{Aim of literature review}

This systematic review aims to fill a gap and capture what some of the cultural, social and ecological contributions that may assist Maōri rangatahi and their whānau succeed in the work environment. We explore and identify the pooled contributions towards successful pathways and wellbeing for whānau members' transitions to the work environment. Relevance to the aforementioned mana (sociocultural and psychological wellbeing) traditions and wairua (spirituality) factors are considered. These key factors are interwoven, and their importance considered in relation to the development of positive and supportive environments which link to job retention, satisfaction and productivity in the workplace. This in turn can have beneficial knock on effects for not only the New Zealand economy, but more importantly for enhancing sustainable livelihoods for upcoming generations (see for example, Kerehoma, Connor, Garrow \& Young, 2013; Henry et al., 2018; Author and colleagues, 2014). By unlocking the potential of rangatahi, Māori communities are contributing to the benefit of the whole country, as well as providing for greater well-being of whānau, hapu (sub tribe) and iwi (tribe).

\section{Method: Research protocols}

Searches on Google Scholar and the university library portals of relevant literature were undertaken for criteria inclusion to identify what previous research for, by and with 
Māori had identified as markers of success for whānau members entering and/or in the employment context. Research was analysed from the year 2005 onwards. This review of research drew upon work that supported Māori sustainable livelihoods and incomes within the evolving nature of workplaces for whānau. An additional criterion was that the research would be situated in environments where the focus was premised on mana empowering or wellbeing practices for whānau. Thus, this body of literature was drawn together and reviewed to extract key characteristics of mana.

A Kaupapa Māori braided river research approach was utilized, where European and Māori $\underline{\text { research methodologies are braided together like the differing streams winding together down }}$ a mighty river leading from the mountains, across the plains to the sea (Authors et al. 2015). Thus, all members of the research team were charged with searching for mana enhancing literature within the above outlined criteria. This was not only through using existing European based library search engines, but also by using their own Indigenous networks and knowledge. Following this, the research articles were presented at our research team hui (meeting) and each team member presented a set of articles for discussion. This was approximately three to six articles per team member. Collaboratively, the research team discussed, reflected and decided which research articles best fitted our mana enhancing criteria. Later, after this hui, further articles were located using various techniques including forward mapping and back mapping of the reference lists of the initial articles. These articles were brought to following hui for discussion.

Two key themes evolved from the review of the literature. Firstly, identifying protective factors of resilience for supporting sustainable livelihoods situated from a Māori worldview (Marsden, 2003). Secondly, when considering mana there is a fundamental 
emphasis for strengths-based practices around the renewal, inclusion and investment for whānau in the workplace in New Zealand (Keelan, 2014).

This review also explored what research has to say about practices that support the economic prosperity, wellbeing and sustainable livelihoods for some whānau in today's world. Specific research investigations exploring practices which support ngā rangatahi (young Māori adults), to attain sustainable incomes, wellness and success for rangatahi proved to be difficult to uncover. Apart from transitioning to the workplace from the education system (Author and colleagues, 2014), and the high mobility between jobs and occupations, the perceptions of the educational link to future career development and the process of sourcing social capital for career direction (Cunningham, Fitzgerald, \& Stevenson, 2005) and the impact of Private Training Enterprises on training Māori students into the workplace (Phillips \& Mitchell, 2010), there was minimal research on successful links of rangatahi to quality based retention and prevention of burn out rates in the workplace environments. Due to the dearth of research in this specific area, to help build on this area of knowledge, studies that involved Māori adults surrounding the topic of this investigation were also explored. We turned to research which promulgated sustainable livelihoods for pākeke (Māori adults) where some of these practices may be applicable to rangatahi as well. Review material included cultural, socialization and ecological practices in the workplace.

To frame the review of research literature question, we compiled two areas of inquiry. First, what does the research have to say about ways to enhance mana (prestige, authority, control, power, influence, status) and sustainable livelihoods in the workplace for Maōri whānau? Here mana skills are reviewed in a wide range of workplaces which enables career pathways and mechanisms to support the enterprises of Māori whānau within New Zealand (see, Henry, Dana \& Murphy, 2018; Gibson et al., 2017; Simpson et al., 2016). Second, we 
sought to uncover some key indicators for Māori whānau members when transitioning to the work place and being part of sustainable enterprises.

\section{Review of literature}

Emerging from the review of the literature were four key themes for mana constructs: i) mana motuhake (having a strong sense of self: whānau identity, attitudes and values); ii) mana ūkaipō (knowing one's connections to place and ancestral origins); iii) mana tangatarua (being confident walking in two worlds; making the transition from education to work); iv) mana tū (building resilience and positive relationships in the workplace). All of these mana constructs help to convey socially acceptable behavioural standards in a work setting. They help to guide interpretations of work-based phenomena, choice and decision-making styles, career development and interpersonal relations (Reid, 2011; Schnurr, Marra \& Holmes, 2007). We then draw upon wairua (spirituality) as it sits and provides the glue within and amongst all of the mana traditions in a whānau context.

\section{Mana motuhake (whānau identity, attitudes and values)}

The importance of culture to mana motuhake and the symbiotic relationship between the home/family environment and the Aotearoa New Zealand workplace environment are foundational for whānau wellbeing and the communities they continue to exist within. Considering many Indigenous cultures, their values and customs, and the role these may play in enhancing wellbeing and satisfaction are all encompassing and of benefit to the community, rather than the individual (Dana, 2015). For example, as Dana explains for Māori and the Aboriginal people in Canada, the ownership of land aligns closely with their Indigenous rights to hunt, fish, and gather fauna and flora for the wellbeing and sustenance of their wider community. 
Brougham, Haar and Roche's (2015) study explored the importance of cultural understanding in a multicultural country, and provided useful insights into the positive effects that work and family can have on cultural attitudes. The study surveyed 172 Māori employees in 14 New Zealand organisations. Two factors emerged: workplace-culturalwellbeing and workplace-cultural-satisfaction. Alignment with a strong cultural orientation towards collectivism in the workplace has benefits for Indigenous or Māori employees. Collectivism was beneficial at all levels of both work-family and family-work enrichment with regards to satisfaction, with those who identified high collectivism reporting higher workplace-cultural-satisfaction at all levels of enrichment. The findings from this study found that collectivism had a bi-directional relationship between work-family and familywork enrichment.

Reid (2011) in her New Zealand study explored how Māori cultural values can impact on careers. The author used semi-structured interviews with 22 Māori to examine the dynamic cultural contexts in which career processes had been enacted. The participants' career life stories were collected to clarify the relationship between cultural values and career processes. Key questions were asked, such as, who were significant people and events in the research participants' working lives; what the meaning of being Māori is in their working life; and the meaning of the word 'career' to them. The interviews occurred in three stages. Reid (2011) used a typology of 'keeper', 'seeker' and 'cloaked' to position the 22 research participants. The 'keepers' retained cultural values, had strong knowledges and experiences of cultural traditions and use of Te reo Māori (Māori language). They often referred to a sense of duty to support and help Māori. The 'seekers' were exploring new possibilities and ascertaining their life meaning by comfortably moving in and out of non-Māori and Māori worlds. Finally, the 'cloaked' located a cultural identity that was meaningful to them. They tended to have a random quest for cultural identity. While not denying their Māori heritage, 
they did not make it overtly identifiable. Reid (2011) suggested that Māori cultural values are dynamic which help to inform career processes. A representation of how cultural values were enacted in career processes was dependent on the diverse range of expressions of being Māori.

Entrepreneurship in the mainstream screen industry by Māori illuminates Indigenous ventures that empower and enhance wider understandings of Māori values and traditions. Henry et al., (2018) investigated ten case studies of Māori entrepreneurs in the screen industry (film and television) and used a year-long series of structured interviews. Kaupapa Māori entrepreneurship is underpinned by imperatives to enhance the well-being and wealth of the community, rather than an individual (Henry, 2007). All of the entrepreneurial participants embedded Māori-centric 'work rooted in the Indigenous storytelling with a strategic focus on Māori cultural revitalization and Māori entertainment” (p.129). The study found that these entrepreneurs were significantly higher educated than other members of the Māori community. Along with this higher education, there appeared to be a positive flow-on influence by the mainstream socialization that occurred during studies, which supported their career aspirations. Another finding was that the Māori screen industry was founded around the history of Māori activism. Henry et al., (2018) suggest that the participants were aware of the dynamics and tensions in an established industry from their own cultural lenses, but were also cognisant of economic imperatives. Highly evident amongst the Māori entrepreneurs was a strong sense of self efficacy, the use of story-telling within the screen industry to contextualise their cultural values, and the entrepreneurs' sustained connections with their whānau and iwi (tribes). Entrepreneurship was enhanced when the social capital and networks were supported by cultural capital (Light \& Dana, 2013).

Myre's (2016) research explored the attitudes of 15 New Zealand university staff members from departments across the university who had varying levels of fluency in te reo 
Māori (Māori language), and their attitudes to the use of te reo Māori in the workplace. The author concluded that the motivation to develop personal te reo Māori skills was dependent on whether the support from the employers was passive or active. When a workplace had an initiative promoting the acquisition and use of te reo Māori, this improved the motivation for employees to undertake te reo Māori courses and use it within their workplace. Although the participants were divided in their opinions of whether learning te reo Māori should be compulsory in the workplace, they did strongly advocate that employers and managers should actively encourage the learning and revitalisation of te reo Māori. Organised events for employees to meet up and practice and develop their use of te reo Māori were sought by the research participants. In general, Myre's work called for further research and initiatives to promote the use of te reo Māori in workplaces.

These studies exemplify the link between culture and mana motuhake (whānau identity, attitudes and values). In the New Zealand workplace environment, for Māori, there is an interdependent association connecting their home/family environment, whānau wellbeing and that of their wider communities to their engagement and motivation within the workplace. Employees need to understand these connections, if they are to understand and protect the wellbeing of their Indigenous workforce.

\section{Mana ūkaipō (place and environmental functions)}

One way of explaining mana ūkaipō is the synchronicity between a mother and its child, such as breast feeding the child. An extension to this explanation of mana ūkaipō lends itself to the nurturing and responsibility of the care between whānau and their tribal lands and waters. Similar to the enterprises of other Indigenous peoples which often are embedded in environmental sustainability (Dana, 2015), Māori protected their resources for upcoming generations, whilst carefully harvesting only what was needed for the wellbeing of their whānau. For example, kaitiakitanga (stewardship) used for caring for resources from whānau 
lands, harvested and prudently onsold valuable resources, such as harakeke (flax). Harakeke was used for the shipping and rope industry and was a source of economic sustenance and agency for whānau prior to colonisation (Orange, 2014). These types of interconnected and co-evolving entrepreneurial systems have supported the advancement of prosperity for many Indigenous communities throughout the world (Dana, 2015).

Panelli and Tipa (2007) and Dana and Hipango (2011) highlighted that Māori, similar to the marginalisation of other Indigenous peoples in the world, have had minimal input to the post-colonial sustainability and ecological wellbeing of the natural resources which maintained the livelihoods of their ancestors. The special affinity that Māori have to the land is evident in their deep respect for the Indigenous flora and fauna. In the research by Dana and Hipango (2011), the interviews with Māori university students and a practitioner of Rongoā Māori (Māori medicine) found that Indigenous plants were a key part of their cultural knowledge and values. The respondents shared how the Te Rapana Trust treated patients using 'culturally tailored' healing using flora and fauna for medicine. When these rights to natural resources, such as flora and fauna and waterways, have been stripped away by westernised neoliberal and corporate ideology, protecting and maintaining mauri (life force) and wairua (spirituality) are seriously at risk. However, when kaitiakitanga (guardianship or management of land, sea and rivers) is implemented it helps to bolster whānau economy and independence, opposed to poverty and state dependence (Kawharu, 2019). Economic development and the growth of communities are central to the improvement of people's livelihoods and wellbeing. Nevertheless, as Dana and Hipango (2011) found, Māori perspectives vary on whether flora and fauna should be used for economic gains to empower iwi. Some were concerned that money de-personalises transactions and commercial use of flora and fauna is not appropriate, while others were more open to developing economic prosperity for their whānau economy. The underlying theme of protecting and enhancing the 
wellbeing for the wider Māori community, which is underpinned by Māori cultural values and respect for environment is situated from traditional customs and knowledge.

Similarly, Kawhura's (2019) 'Pā (Māori village) to Plate' programme imbeds Indigenous concepts into a community value chain which incorporates the circular values such as taking part in marae pā (carved buildings and grounds of a village that belongs to a particular iwi, hapū or whānau) gardening and returning food scraps back to the land or animals. The centrality of cultural values and the role of whakapapa (genealogy, descent) are highly evident within this value chain.

Stein, Mirosa and Carter (2018), investigated a mana enhancing programme that was premised on four Māori women's community-based leadership and mana ūkaipō (place and environmental functions). The study reported on māra kai or successful traditional food production, biodiversity protection and cultural resurgence of traditional Māori food. The authors discussed how the research participants used mana wāhine (Māori female leadership) to understand and disseminate whānau based knowledge that related to variations of localised food security systems in practice. The methodology used a convergence approach towards participatory action and Māori centred principles, such as, mana enhancement of subsistent and successful kai production. For example, the participatory focus was placed upon collaboration and knowledge exchange, and the Māori centred emphasis was situated around the issues of food production, access to resources and unemployment.

Mana ūkaipō and māra kai (harvesting and growing of food) are positive practices community kai systems and they promote good oranga (health) that reconnects some whānau with the land (Stein et al, 2018). The work of Stein and colleagues highlighted the role of mana wāhine (female leadership) in teaching respect and appreciation of traditional māra kai practices to promote future kaitiakitanga (guardianship and protection) of their land. 
Sustainable practices as māra kai aims to boost the level of whānau involvement that align with community gardening projects intended to produce health, financial and social benefits. Further, these practices address sustainable whānau practices that are housed within community based participatory action and kaupapa (set of Māori values, principles). One question around sustainable food practices and knowledge transfer is that whānau in this study were domiciled in rural contexts where access to food was closer between whānau. However, for pan tribal urban whānau in cities and larger towns, the sustainable practices of māra kai is problematic as food and access to land may be harder to access.

\section{Mana tangatarua (alternating with the transition from education to work)}

Education can be life-long and is a key pathway to enduring chances of prospering in society. Author (2010) explains how the visible lack of understanding a Māori worldview in mainstream Aotearoa New Zealand may be a significant precipitator of why a number of Māori students underachieve in a schooling education and/or are excluded from it. He asserts that in a society, which is often depicted as bi-cultural or multi-cultural, underachievement is frequently 'explained away' by pathologising students on the base of supposed cultural deficits. However, it is increasingly common for services such as health, social welfare and education to be formed to accommodate the differing cultural background of the people who access these services (Author2010).

One example of whānau success, was the Ka Awatea study which reported successful accounts of Māori secondary school leavers (Author et al., 2014). The authors identified some significant antidotes to deprivation, exemplified by the construct and enactment of 'mana', in various forms. Four replenishing mātauranga (educational) subject matters emerged from the study. Firstly, mana motuhake (whānau identity, attitudes and values) was 
a positive context of Māori identity where the students engaged meaningfully with their

Māori culture. Additionally, these students' behaviour in wider society were underpinned by Māori values such as manaakitanga (reciprocal hospitality and respect from one individual or group to another) and māhaki (being inoffensive, humble and tolerant). Secondly, the theme of mana tū, (a sense of courage and resilience) was critical. The successful Māori students in the study had developed a positive self-efficacy and self-concept, had high expectations and enjoyed physical, emotional and spiritual wellbeing. The next area was mana ūkaipo, where a sense of place was evident and the learning was related to the context was key to these successful Māori rangatahi school leavers. Finally, the theme of mana tangatarua, where there is a sense of being able to navigate between two worlds, was apparent amongst these rangatahi, and is key to many Māori living in the $21^{\text {st }}$ century. Importantly, in Author and colleagues' (2014) study, the Māori secondary students' academic success did not come at the expense of their Māori identity.

Similar to the Ka Awatea successful secondary students, the Māori participants in the study by Henry, Dana and Murphy (2018) of entrepreneurs in the New Zealand screen industry, the emerging themes were greater levels of education especially at tertiary level, a clear sense of self-efficacy and strong connections with their whānau and iwi. (see, Henry et al., 2018; Hipango \& Dana, 2012)

Education, whether it be at secondary or tertiary levels or in workplace settings can be central to improving outcomes for Māori. Understanding the fundamental enablers for Māori to be engaged and succeed in the workplace is crucial. In this endeavour, supporting Māori in workplace settings, was the focus of a study by Kerehoma, Connor, Garrow and Young (2013). They used a qualitative approach and conducted interviews with 34 Māori learners engaged in industry training, such as apprenticeships. They conducted focus group interviews 
with 35 key stakeholders, including employers, Industry Training Organisation field staff, iwi representatives and career advisors. The study found that key enablers were multi-layered. A tuakana-teina model (reciprocal peer learning and mentoring), connectedness with the employer and work colleagues, along with whānau support and encouragement were needed. On an individual level, similar to the Ka Awatea research (Author et al., 2014) findings, values such as commitment and mana tū (courage and resilience), and mana ūkaipo (sense of place) and belonging were crucial.

Encouraging Māori into career pathways that support their own whānau and iwi provides a sense of connectedness. This connection underlies the key value of whanaungatanga, where there are strong relationships incorporating reciprocity and trust (Kerehoma et al., 2013; Mooney, 2012). For example, Campbell's agenda in advancing Māori and Pacific workforces in the District Health Boards in Aotearoa New Zealand, incorporated a strategy for rangatahi and scholarship. This was underpinned by the philosophy of developing awareness in Māori senior secondary school leavers of the number of Māori and Pasifika who are patients in healthcare institutions. The authors asserted that Māori and Pasifika patients would benefit from having a higher percentage of their own people working in the health field (Manchester, 2012). The provision of culturally appropriate mainstream healthcare and Māori specific services allows for a kanohi ki te kanohi (face-to-face engagement) with health care workers who are culturally aware of best ways forward in supporting patients and their whānau during times of personal crisis.

Mooney's (2012) research exploring the connectedness between social workers and rangatahi with hauora hinengaro (mental health) needs, once again reinforces the replenishing themes evidenced in the Ka Awatea research discussed earlier. When Māori social workers 
have a Māori worldview and utilise culturally appropriate practices and values with the rangatahi and their whānau, a more positive rapport is readily established. By engaging rangatahi as key personnel and creating an environment that is client-centred with trust and respect as key drivers, the rapport of the relationships is enhanced. In brief, whānau education and achievement echoes the importance of relational aspects such as humour which is shown in the next section.

\section{Mana tū (building resilience, courage and positive relationships in the workplace)}

Humour is an effective strategy when applied for negotiating leadership within some organisations where Māori etiquette and values prevail. Humour helps to build and enact many types of relationships in the workplace, and to express many layers of meaning. Holmes (2007) examined how some Māori leaders workplace humour, communication and delivery of kaupapa in their leadership behaviour within particular workplace situations enhanced relationships with work colleagues. The authors employed a qualitative approach by using written excerpts taken from six interviews to exemplify leadership and in tandem workplace humour at the start of meetings and the subsequent proceedings of the meeting. For example, self-deprecation humour was used in response to praise as a strategy of whakaiti (modesty). Although this study addressed some important aspects of humour in a Māori workplace, it could have also indicated future research purposes such as whether or not humour has a link to commercial productivity within the Māori workplace context and its wider implications towards the Māori economy. Nevertheless, this research makes a unique contribution to understanding a number of aspects of Māori leadership research by focusing on the role of whānau based strategies such as workplace humour. It highlights the use of a formalised process with the meeting starting with a karakia (prayers or incantations composed for a variety of functions in the workplace: protection and safety for the group). 
When praise has been shown towards leadership in the meeting, the praise is then responded with self-deprecation humour to show some level of whakaiti (diminishment).

The ways in which leaders in diverse workplace communities develop as effective leaders with their staff when they incorporate protocols and values such as politeness and contestive behaviours can differ. In Schnurr, Marra and Holmes (2007) the discourse was situated in the team meeting setting where excerpts were used with two Māori and two Pākehā (non-Māori) case studies. Team meeting aspects such as the formality and protocols of different work groups (for example, opening of meetings) and the ways in which contestive behaviour with humour were addressed in this study. The study helped to glean some understanding of politeness and contestive humour in one group, but may be considered inappropriate in members of another group. For instance, the Māori workplace groups showed a formalised style of meeting opening, whereas in the Pākehā workplace there was often a more relaxed style of meeting opening. Similarly, what is considered amusing associated with cultural values and different backgrounds and the way humour is employed contributes to the distinct community practices. For example, using an amusing performance of a workplace transgression through the use of te reo Māori can be conveyed in an indirect manner. Generally, a statement is made and people to whom it implies are expected to infer its relevance to them.

Achieving Māori leadership objectives can be sustained through the use of reinforcing politeness, by not pointing the finger at the group if a transgression has taken place. Through the use of group humour to indirectly get the message across to the transgressor(s), this can be a subtle way which can often diffuse a challenging situation. Another general aspect indicative of Māori respect and politeness is the sensitivity to status differences. Similar to a pōwhiri (formal welcome) in the workplace, the group members will make a subtle reminder of the leadership position which indicates respect for the leader. The take home point for 
Māori leadership to continue is by maintaining and preserving mana within the group by using the above strategies. In turn, mana executed by Māori leadership may link to cultural maintenance of wellbeing in the work environment.

Hipango and Dana (2012) explored the links between culture and entrepreneurial efficacy for Māori. Being self-employed and setting up a small business are central to entrepreneurship. Their analysis of data from the Global Entrepreneurship Monitor found that Māori (60\%) were more likely to know entrepreneurs than their non-Māori counterparts (40\%). Knowing an entrepreneur has the benefit of being part of their social network which provides an important resource in terms of social capital and key links and knowledge of the ways to succeed in setting up a business or becoming self -employed. Hipango and Dana explain how Māori entrepreneurship is woven together with culture and/ or the environment. For example, the work of Keelan and Woods (2006) promulgates the term 'Māuipreneur' when reflecting on the narratives of the heroic Māori ancestor Maui, whose entrepreneurship and courage and self-determination positions entrepreneurial actions within the Māori worldview.

To supplement the four mana constructs discussed, we now draw upon the intrinsic and multidimensional element of wairua (spirituality).

\section{Wairua (the invocation of physical and spiritual processes)}

Wairua tahi (physical embodiment) and wairua (the part of the person that dreams) and how this wairua guides the person through their life is developed by internal and external influences. In trying to define wairua, Foster's (2009) work found that three research participants agreed that wairua was a difficult concept to articulate and therefore define. They maintained that wairua was multidimensional which changed depending on the context in which it was being used. Operational definitions of wairua may become problematic in a 
research context because of its multifaceted phenomena that it exemplifies. Foster's (2009) research found that the participants universally agreed that wairua is viewed by whānau generally as being linked to beliefs, attitudes and values maintained through customary rituals protocols and practices. Furthermore, wairua is a normal way of life for whānau which are affirmed through daily interaction and practice (Foster, 2009).

While contemporary individual Māori members may embrace traditional Māori culture to varying degrees, Te Ao Māori (a collective Māori world view) defines a distinctive common context indexed by wairua. The juxtaposition of Māori and European cultures presents an opportunity to contrast the highly spiritual nature of Māori culture with European traditions of linearity and rationality. This contrast can be especially appreciated in the consideration of career processes, such as, opening of meetings for whānau using a karakia or an affirmation, aphorism, prayer or incantation (Schnurr, Mara \& Holmes, 2007).

Further, mana wairua provides another base for potentially considering career decisions which may impact upon status and wellbeing of self, whānau, hapū and iwi. Durie (1994, p. 70) states that Te Taha Wairua (the spiritual domain) is:

“...generally felt by Māori to be the most essential requirement for health. It implies a capacity to have faith and to be able to understand the links between the human situation and the environment. Without a spiritual awareness and a mauri (spirit or vitality, sometimes called a life-force) an individual cannot be healthy and is prone to illness or misfortune. A spiritual dimension encompasses religious belief and practices but is not synonymous with regular church going or strong adherence to a particular denomination. Belief in God is one reflection of wairua, but it is also evident in relationships with the environment, land, lakes, mountains, reefs have a spiritual significance quite apart 
from economic or agricultural considerations, and all are regularly commemorated in song, tribal history, and formal oratory."

\begin{abstract}
As Durie (1987) explained, Māori belong to their whānau and land. Land provides a place for Māori to stand, which is foundational within the concept of mana tū, (a place to stand and environmental functions) and where whānau are safe and protected. The land, lakes, rivers and sea are cloak the basis of maintaining whānau based systems for economic wealth and wellbeing such as food sovereignty, accessibility and security (Mead, 2016).
\end{abstract}

Finally, we would like to broach the impediment of cultural taxation that some Māori are encountering in their workplaces and communities.

\title{
Cultural taxation
}

Frequently, Māori working in workplace environments are expected to fulfil cultural tasks and ceremonies with little recognition. Research investigating teachers in New Zealand mainstream schools found many were the victim of cultural taxation by non-Māori leaders and colleagues (Authors and colleague, 2018;Author and colleague, 2018). School principals hold a key role as significant others in leading and supporting culturally responsive bicultural schooling. For some of the research participants, professional development in culturally responsive pedagogies would have alleviated the multifaceted issues that the Māori teachers confronted. The absence of awareness of tikanga Māori (cultural rituals and practices) was frequently cited by participants. Furthermore, collegial misunderstandings or collegial 'ignorance' in the facilitation of professional development sessions were evident.

The additional professional and cultural tasks and responsibilities that this group of Māori teachers undertook frequently were not recognised financially or otherwise by their employers or fellow colleagues. Often, the teachers would define themselves as 'ambassador- 
at-large' or a 'one-stop-Māori-shop'. Nonetheless, the participants had a deep commitment to being ethically obligated to undertake these roles. The Māori teachers had a sense of being 'culturally obliged' to tautoko (support) the students and aid their schools' own Māori communities as 'fellow Māori'. This profound sense of duty, considerably enlarged their likelihood of feeling 'overwhelmed' 'stressed', 'tired' and 'burnt-out'.

This tendency, which also leaves Māori teachers feeling isolated, creates additional workload pressure for the participants and recurring feelings of 'burn-out'. This trend, therefore, has the potential to undermine the implementation of the Ministry of Education's national strategy for Māori education (Ka Hikitia) within the Waitaha region and, possibly, elsewhere in New Zealand. Given that Ka Hikitia advocates "Māori enjoying educational success as Māori” (Ministry of Education, 2008, p.18), it is difficult to see how this admirable goal will be achieved locally and nationally, especially if Māori teachers feel 'burnt-out' as a result of being assigned additional duties that take their real workloads well above their official workloads with no recompense and little or no recognition.

It could also be argued that the 'cultural taxation' identified in author and colleague's (2017) research, amounts to a breach of the Treaty of Waitangi principle of 'active protection' in the sense that not enough is being done to actively protect the wellbeing of Māori teachers who are critical to the implementation of official Māori education policy guidelines. 'Bi-cultural practitioners', such as those envisaged by the New Zealand Teachers Council Registered Teacher Criteria and the Professional standards for school leaders, require teachers and principals to be capable of performing tasks such as actively participating in hui and pōwhiri. The failure of the Crown to ensure that this is the case also suggests failure to ensure that the principles of 'partnership' and 'participation' are fairly applied. 
This also raises questions about the Crown's efforts to 'actively protect' Māori culture within the participating schools (and schools elsewhere). It is hard to see how Māori students will 'enjoy educational success as Māori', if Māori teachers themselves are left feeling burntout and/or professionally isolated and leave the teaching profession as a result.

\section{Whakamutunga (conclusions)}

Enterprising and entrepreneurial practices by Indigenous communities that support the sustainable prosperity and sustenance for all people includes having access to healthy food, water, shelter, and safe places to live, lead to good health and emotional well-being (Dana, 2015). Developing and maintaining these basic elements of sustenance are complex. The political nature of what constitutes equitable and effective policies, who is empowered to instigate and make these decisions, and recognition and knowledge of culturally accepted practices of the Indigenous people reflects this complexity (see, Dana, 2015; Hipango and Dana, 2012). Underpinning this is that access to these resources, which are the foundational tools of wellbeing and sustenance, has high-stakes value for individuals, cultural groups and differing socio-economic strata of wider society. As Sinclair (1981, p. 86) explained, 'Ma te whenua ka whai oranga ai (Land alone gives man his sustenance)'. There is a spiritual relationship for Māori with land, where, for example, over hundreds of years the forests were nurtured by Māori as sources for medicine, food, timber for homes, ocean-going waka (canoes) and weapons. Hipango and Dana (2012) found in their research on better understanding Māori perspectives on economic enterprise in relation to flora and fauna that Māori had strong links to the land and waterways of Aotearoa New Zealand. The Indigenous plants and their uses by their ancestors as sources of nourishment and medicine were deeply rooted in Māori cultural practices. These were guided by sustainable practices to ensure the benefits for future generations. The tribal lands were traditionally cultivated with crops, such as kumara (sweet potato) providing kai for whānau. These environmental functions are 
highlighted within $21^{\text {st }}$ century Aotearoa New Zealand by mana wāhine in Stein, Mirosa and Carter's (2018) research, where collaboration and leadership allowed for the community gardens in rural areas. With the urbanisation of many Māori over recent decades, the promotion of such community gardens within the confines of cities can be advocated and promulgated. Kawharu's (2019) research on reinterpreting the value chain for Indigenous people in Aotearoa New Zealand are under pinned by guiding values. Such community based enterprises provide strong role models for positive and affirmative change for prosperity for marginalised Indigenous people throughout the world.

As Durie $(1987,1994)$ and Foster (2009) remind us, the mana wairua of Māori culture has a different outlook on land and the greater forces of the world, than European cultures. The passing of the knowledge in practices of sustenance from one generation to another, gives the mauri which is reflected in the close relationships of Māori with land, rivers, sea, lakes, mountains and forests. In actuality there is connectedness between traditional practices of sustenance, that challenge policy makers to investigate surrounding perceptions around maintenance of the status quo, and how effective governmental policies and practices can be further advanced to ensure that the rights of the Indigenous owners of the land are protected.

Across the studies of sustainable and entrepreneurial enterprises that promote prosperity for Māori, there was a collective cluster of components associated with practices identified as effective. Most significantly was the importance of culture to wellbeing within the workplaces and the strong connections to whānau and iwi (see, Hipango \& Dana, 2012). Henry et al., (2018) in their research on Māori entrepreneurs in the screen industry found that the power of storytelling of Māori narratives provided differing lenses to the mainstream screen industry. Provocation that had motivated many of these entrepreneurs was activism towards the severe constraints to their ancestors and whānau of colonisation. 
The use of humour as an effective strategy to build and enact positive relationships with and amongst Māori in the workplace (Holmes, 2007) and the protocols identified in Schnurr, Marra and Holmes (2007) research on Māori and Pākehā leaders in the workplace illuminated insights into promoting nurturing workplaces for Māori. Another feature was evident in the transitioning from secondary schooling into the workforce or tertiary study in the Ka Awatea study (Macfarlane, et al., 2014) where strong Māori values were highly evidenced. Underlying this was the academic success for these Māori school leavers was not compromised by their Māori identity. This aligned with findings in the study by Henry et al., (2018) of successful Māori entrepreneurs in the screen industry.

Torepe and colleagues' research $(2017$; 2019) exemplified the scars of colonisation upon Māori educators as they battle to revive the Māori language and tikanga in schooling upcoming generations of New Zealanders. The profound sense of duty felt by Māori educators to tautoko (support, encourage) students and fellow educators has compromised their own wellbeing with higher reported levels of stress and burn out when these additional duties are not reflected within their workloads. What author's research does tell us is that when educators are supported by ministry of education policies and funding, based on research evidence of effective practices that sound practices to support Te Reo Māori and tikanga in all schooling can be implemented.

Coupled with these issues is the sheer difficulty of implementing change. Change is politically and systemically situated. A limitation of this review on sustainable prosperity for rangatahi is that the studies are gathered from a range of age groups. Arguably, this may not capture the challenges confronting the younger generations in a very digitally advanced society where online communication is becoming the norm rather than kanohi ki te kanohi (face to face) interactions which are implicit in Māori tikanga. We contend the value of gaining an overall perspective on how research on sustainable livelihoods for Māori can add 
to our understandings. Nonetheless, the wider systemic factors, such as the ongoing impacts of colonisation and the ambiguity and inequities enacted within the two versions of the Treaty of Waitangi confrontationally shape and influence the wellbeing and realities for Māori within New Zealand.

This literature review expanded on the mana principles that were theorised in the Ka Awatea study (Author et al, 2014). The four mana principles that were evident from the review of the literature were mana motuhake, mana ūkaipō, mana tangatarua and mana tū. We recommend future research which explores how to move forward from this review, to a platform for an applied community-based study that implements the four mana principles. 


\section{References}

Au, K. (2000). A multiculural perspective on policies for improving literacy achievement: Equity and excellence. In M. Kamil, P. Mosenthal, P. Pearson, \& R. Barr (Eds.), Handbook of reading research (Vol. 3, pp. 835-870). Mahway, NJ: Lawrence Erlbaum Associates.

Bishop, R. (2005). Freeing ourselves from Neocolonial domination in research: A Kaupapa Māori approach to creating knowledge. In N. K. Denzin \& Y. Lincoln (Eds.), The Sage Handbook of Qualitative Research (Third ed., pp. 109-138). Thousand Oaks: Sage.

Brougham, D., Haar, J., \& Roche, M. (2015). Work-family enrichment, collectivism, and workplace cultural outcomes: a study of New Zealand Māori. New Zealand Journal of Employment Relations, 40(1), 19-34.

Chamberlain, M., \& Caygill, R. (2013). Key findings from New Zealand's participation in the Progress in International Reading Literacy Study (PIRLS) and Trends in International Mathematics and Science Study (TIMMS) in 2010/11. Wellington: Comparative Education Research Unit.

Cunningham, C., Fitzgerald, C., \& Stevenson, B. (2005). Pathways to employment: an analysis of young Māori workers. Auckland, NZ: Labour Market Dynamics Research Programme, Massey University.

Dana, L. P. (2015). Indigenous entrepreneurship: an emerging field field of research. International Journal of Business and Globalisation, 14(2), 158 - 169.

Dana, L. P., \& Hipango, W. J. (2011). Planting seeds of enterprise: Understanding Māori perspectives on the economic application of flora and fauna in Aotearoa (New Zealand). Journal of Enterprising Communities: People and Places in the Global Economy, 5(3), 199-211. https://doi.org/10.1108/17506201111156670

Department of Labour. (2009). Māori in the New Zealand labour market. Wellington: Department of Labour.

Durie, M. (1987). Tribal authorities as advocates for Māori health. Wellington: New Zealand Board of Health, Māori Health Committee.

Durie, M. (1994). Whaiora: Māori health development. Auckland: Oxford University Press.

Foster, G. (2009). Conceptualising wairuatanga: rituals, relevance and realities, University of Canterbury).

Gibson, K., Abraham, Q., Asher, I., Black, R., Turner, N., Waitoki, W., \& McMillan, N. (2017). Child poverty and mental health: A literature review. Wellington: Child Poverty Action Group, The New Zealand Psychological Society.

Henry, E. Y. (2007). Kaupapa Māori entrpreneurship. In L. P. Dana \& R. B. Anderson (Eds.), International Handbook of Research on Indigenous Entrepreneurship (pp. 536 - 548). Northhampton: MA: Edward Elgar.

Henry, E. Y., Dana, L. P., \& Murphy, P. J. (2018). Telling their own stories: Māori entrepreneurship in the mainstream screen industry. Entrepreneurship and Regional Development, 30(1-2), 118145. https://doi.org/https://doi.org/10.1080/08985626.2017.1388445

Hipango, W. J., \& Dana, L. P. (2012). Culture and entrepreneurial efficacy: using GEM data to explore opportunity and capability in relation to firm longevity. International Journal Entrepreneurship and Small Business, 16(2), 199-222.

Holmes, J. (2007). Humour and the construction of Māori leadership at work. Leadership, 3(1), 5-27.

Jackson, M. (1989). A Summary produced by Project Waitangi of Moana Jackson's report, The Māori and the criminal justice system : he whaipaanga hou = a new perspective. Wellington, NZ:

Kawharu, M. (2019). Reinterpreting the value chain in an indigenous community enterprise context. Journal of Enterprising Communities: People and Places in the Global Economy, 13(3), 242262.

Keelan, T., \& Woods, C. (2006). Māuipreneur: understanding Māori entreprenuership. The International Indigeous Journal of Entrepreneurship, Advancement, Strategy and Education, 2(1), 1-20. 
Keelan, T. J. (2014). Ngā Reanga: Youth Development. Auckland: Unitec.

Kerehoma, C., Connor, J., Garrow, L., \& Young, C. (2013). Summmary report: A model for successful Māori learners in workplace settings. Wellington: Ako Aotearoa National Centre for Tertiary Teaching Excellence.

Light, I., \& Dana, L. P. (2013). Boundaries of social capital in entrepreneurship. Entrepreneurship Theory and Practice, 37(3), 603 - 624. https://doi.org/https://doi.org/10.1111/etap.12016

Author (2010).

Authors and colleagues . (2017).

Authors and colleagues. (2015)

Author and colleagues.-(2014)

Manchester, A. (2012). Advancing the Māori and Pacific workforce. Kai Tiaki Nursing New Zealand, 18(3), 29.

Marsden, M. (2003). The woven universe: selected writings of Rev. Māori Marsden. Otaki, NZ: Estate of Rev. Māori Marsden.

Martin, R. (2017). Te Whakarauora Reo Nō Tuawhakarere - Giving our children what we missed out on: Māori language revitalisation for Māori/English bilingualism, University of Canterbury, Christchurch). Retrieved from http://hdl.handle.net/10092/13291.

McGirr, M., \& Earle, D. (2019). Not just about NEETs: A rapid review of evidence on what works for youth at risk of limited employment. Retrieved 2 October, 2019, from https://www.educationcounts.govt.nz/publications/80898/not-just-about-neets

Mead, S. (2016). Tikanga Māori: Living by Māori values. Wellington: Huia.

Mhyre, J. (2016). The attitude of non-Māori second language learners of the Māori language towards Māori language use. Bahnhofstrabe, Germany: Lambert Academic Publishing.

Ministry of Education. (2008). New Zealand Schools: Nga Kura O Aotearoa A Report on the Compulsory Schools Sector in New Zealand 2007 Wellington: Ministry of Education.

Mooney, H. (2012). Māori social work views and practices of rapport building with rangatahi Māori. Aotearoa New Zealand Social Work(24 (3\&4)), 49-64.

Orange, C. (2014). What happened at Waitangi? Wellington: BWB Texts.

Panelli, R., \& Tipa, G. (2007). Placing well-being: A Māori case study of cultural and environmental specificity. Eco Health, 4, 445 - 460. https://doi.org/10.1007/s10393-007-0133-1

Phillips, H., \& Mitchell, M. (2010). It is all about feeling the aroha: successful Māori and Pasifika providers. Lincoln, NZ:

Reid, L. (2011). Looking back to look forward: Māori cultural values and the impact on career. International Journal of Vocational Guidance, 11, 187-196.

Schnurr, S., Marra, M., \& Holmes, J. (2007). Being (im)polite in New Zealand workplaces: Māori and Pākehā leaders. Journal of Pragmatics, 39, 712-729.

Simpson, J., Duncanson, M., Oben, G., \& Wicken, A. (2016). Child Poverty Monitor 2016 Technical Report. Dunedin: NZ Child and Youth Epidemiology Service, University of Otago.

Sinclair, D. (1981). Land: Māori view and European response. In M. King (Ed.), Te ao hurihuri The world moves on: Aspects of Māoritanga (pp. 107 - 128). Auckland: Longman Paul.

Statisitics New Zealand Tatauranga Aotearoa. (2013). Major ethnic groups in New Zealand. Retrieved 3 October, 2019, from https://www.stats.govt.nz/infographics/major-ethnic-groups-in-newzealand

Statistics New Zealand. (2018). Māori unemployment rate at nine-year low, but twice New Zealand rate. Retrieved 2 October, 2019, from https://www.stats.govt.nz/news/maoriunemployment-rate-at-nine-year-low-but-twice-new-zealand-rate

Statistics New Zealand Tatauranga Aotearoa. (2018). Māori population estimates: At 30 June 2018. Retrieved 3 October, 2019, from https://www.stats.govt.nz/information-releases/maoripopulation-estimates-at-30-june-2018

Stein, K., Mirosa, M., \& Carter, L. (2018). Māori women leading local sustainable food systems. AlterNative an International Journal of Indigenous Peoples, 14(2), 147-155. 
Authors and colleague (2018).

Author and colleague. (2018).

United Nations Declaration on the Rights of Indigenous Peoples. Retrieved from http://www.un.org/esa/socdev/unpfii/documents/DRIPS_en.pdf

Waitangi Tribunal. (2014). Waitangi Tribunal; He Whakaputanga me te Tiriti/The Declaration and the Treaty. Retrieved 12 October, 2017, from https://forms.justice.govt.nz/search/Documents/WT/wt_DOC_85648980/Te\%20RakiW_1.p df

Walker, R. (1990). Ka whawhai tonu mātou: Struggle without end. Auckland, NZ: Penguin Books.

Williams, D. (2014). Waitangi Tribunal finds signatories did not cede sovereignty. Māori law review: A monthly review. Retrieved 12 October, 2017, from http://maorilawreview.co.nz/2014/11/waitangi-tribunal-finds-treaty-of-waitangisignatories-did-not-cede-sovereignty-in-february-1840/ 